\title{
PERBEDAAN PERILAKU ETIS PEJABAT PENATAUSAHAAN KEUANGAN DAN BENDAHARA SKPD \\ BERDASARKAN FAKTOR INDIVIDUAL DALAM ETIKA PENYUSUNAN LAPORAN KEUANGAN \\ SATUAN KERJA PERANGKAT DAERAH (SKPD) DI KABUPATEN SAROLANGUN
}

\author{
Eva Setiarini Damanik ${ }^{1}$
}

\begin{abstract}
The purpose of this study is to obtain empirical evidence related to significant differences in ethical behavior between PPK and Treasurer SKPD based on individual factors in the preparation of financial statements SKPD as measured by disclosure, cost and benefit, responsibility, misstate, and timeliness of the preparation of financial statements SKPD. This study will examine whether there are significant differences in ethical behavior between PPK and SKPD Treasurer based on individual factors in the preparation of SKPD financial statements that can be measured by disclosure, cost and benefit, responsibility, misstatement, and timeliness of SKPD financial report preparation. In this study, the disclosure, cost and benefit, responsibility, misstate, and timeliness variable of SKPD financial statements as variables will be measured and compared between two sample groups (PPK and SKPD Treasurer) which have different individual factors (locus of control, long time, gender, equity sensitivity, educational background and self efficacy. The results of data testing related to the analysis of individual factors of PPK and SKPD Treasurer at the Local Government of Sarolangun Regency in the ethics of preparation of financial statements SKPD There is no difference between $P P K$ and SKPD Treasurer with internal locus of control to PPK and Treasurer SKPD with external locus of control in ethics of preparation SKPD's financial statements to the Sarolangun Regency Government are expressed by the variable cost and benefit and timeliness.
\end{abstract}

Keywords: Role of PPK and Treasurer SKPD, Financial Statement Preparation Ethics, Financial Statement SKPD Sarolangun

\section{PENDAHULUAN}

Organisasi sektor publik bergerak dalam lingkungan yang sangat kompleks. Komponen lingkungan yang mempengaruhi organisasi sektor publik meliputi banyak faktor baik ekonomi, politik, kultur, maupun demografi. Penerapan kebijakan otonomi daerah saat ini juga telah mendorong perkembangan akuntansi sektor publik di Indonesia yang terus mengalami kemajuan pesat seiring dengan diterapkannya pelaksanaan otonomi daerah dan desentralisasi fiskal. Salah satu tujuan utama pelaksanaan otonomi

\footnotetext{
${ }^{1}$ STIE GK Muara Bulian
}

daerah dan desentralisasi fiscal tersebut adalah untuk menciptakan good governance yaitu kepemerintahan yang baik. Pemerintah daerah selaku entitas pelaporan keuangan daerah diwajibkan menyampaikan laporan pertanggungjawaban berupa Laporan Keuangan Pemerintah Daerah (LKPD). LKPD terdiri dari Laporan Realisasi Anggaran, Neraca, Laporan Arus Kas dan Catatan atas Laporan Keuangan. LKPD disusun oleh Kepala SKPKD selaku PPKD pada setiap tahun untuk disampaikan kepada Kepala Daerah dalam rangka pertangungjawaban pelaksanaan APBD berdasarkan 
Laporan Keuangan Satuan Kerja Perangkat Daerah (SKPD) dan laporan pertanggungjawaban pengelolaan perbendaharaan daerahSatuan Kerja Perangkat Daerah (SKPD) sebagai entitas akuntansi memiliki pelaku akuntansi yang terdiri dari Bendahara dan Pejabat Penatausahaan Keuangan Satuan Kerja Perangkat Daerah (PPK SKPD), seperti yang dijelaskan dalam Pasal 14 Peraturan Pemerintah Nomor 58 Tahun 2005 tentang Pengelolaan Keuangan Daerah.

(1)Peran PPK dan Bendahara SKPD sangatlah vital untuk mewujudkan administrasi keuangan yang efektif atau dengan kata lain kemampuan dan kecakapannya dalam menjalankan fungsi akuntansi sangat menentukan dalam menyusun dokumen laporan keuangan SKPD. Berbagai sorotan dan tudingan terhadap perilaku etis pelaku akuntansi pemerintahan didalam etika penyusunan laporan keuangan satuan kerja perangkat daerah perlu menjadi perhatian banyak pihak. Untuk mengubah perilaku yang tidak etis atau menciptakan perilaku yang diinginkan, hal pertama yang perlu kita ketahui adalah faktorfaktor individual apa saja yang mempengaruhi perilaku etis pelaku akuntansi tersebut didalam etika penyusunan laporan keuangan satuan kerja perangkat daerah. Tujuan penelitian ini adalah untuk memperoleh bukti empiris terkait perbedaan perilaku etis yang signifikan antara PPK dan Bendahara SKPD berdasarkan faktor-faktor individualnya dalam etika penyusunan laporan keuangan SKPD yang diukur dengan disclosure, cost and benefit, responsibility, misstate, dan ketepatwaktuan penyusunan laporan keuangan SKPD. Menganalisis perilaku etis PPK dan Bendahara
SKPD berdasarkan faktor-faktor individual yang mencakup Locus of Control, Lama Menjabat, Gender, Equity Sensitivity, Latar Belakang Pendidikan dan Self Efficacy.

1) Menganalisis perbedaan faktorfaktor individual yang mempengaruhi perilaku etis PPK dan Bendahara SKPD dalam penyusunan laporan keuangan SKPD yang diukur berdasarkan Disclosure, Cost and Benefit, Responsibility, Misstate dan Ketepatwaktuan Penyusunan Laporan Keuangan

2) Menganalisis perbedaan faktorfaktor individual yang mempengaruhi perilaku etis PPK dan Bendahara SKPD dalam penyusunan laporan keuangan SKPD yang diukur berdasarkan Disclosure, Cost and Benefit, Responsibility, Misstate dan Ketepatwaktuan Penyusunan Laporan Keuangan.

Hasil penelitian ini diharapkan dapat memberikan bukti empiris dan dapat bermanfaat sebagai bahan masukan bagi Praktisi maupun Akademisi

\section{TINJAUAN PUSTAKA}

Etika menjadi perhatian penting masyarakat Indonesia belakangan ini, setelah terjadinya berbagai degradasi moral yang terjadi di kalangan praktisi maupun akademisi, dengan tindakantindakan berupa korupsi dan penyelewengan-penyelewengan yang lain, yang otomatis merupakan suatu pelanggaran terhadap etika, baik etika profesi maupun etika pada umumnya. Perilaku menurut Hidayat (2010) merupakan salah satu komponen sikap. Sikap (attitude) adalah pernyataan evaluative, baik yang menyenangkan maupun yang tidak menyenangkan, terhadap objek, individu, atau peristiwa. Penelitian ini menggali 
aspek perilaku dalam penyelenggaraan laporan keuangan yang dilakukan oleh kelompok pejabat penatausahaan dan bendahara di masing-masing SKPD. Aspek ini merupakan hal yang sangat vital yang dapat mempengaruhi perilaku etis atau tidak etis dalam penyelenggaraan laporan keuangan. Faktor-faktor individual terbukti merupakan faktor yang signifikan untuk memprediksi perilaku etis seseorang (Reiss dan Mitra, 1998). Bahkan menurut Bommer et. al. (1987) faktor individual adalah merupakan faktor yang paling berpengaruh terhadap perilaku etis seseorang Penelitian ini akan meneliti mengenai faktor-faktor individual, meliputi locus of control, lama menjabat, gender, equity sensitivity, latar belakang pendidikan dan self efficacy. Agar pembaca laporan keuangan memperoleh gambaran yang jelas, maka laporan keuangan yang disusun harus didasarkan pada prinsip akuntansi yang lazim, dan di Indonesia prinsip akuntansi disusun oleh Ikatan Akuntansi Indonesia,yang pertama yaitu Misstate ( kecenderngan untuk melakukan salah saji dalam laporan keuangan).Disclosure ( pengungkapan
Laporan Keuangan), Cost and benefit ,Responsibility dan yang terakhir adalah ketepatan waktu

\section{Kerangka Pemikiran}

Penelitian ini akan menguji apakah terdapat perbedaan perilaku etis yang signifikan antara PPK dan Bendahara SKPD berdasarkan faktorfaktor individual dalam etika penyusunan laporan keuangan SKPD yang dapat diukur dengan disclosure, cost and benefit, responsibility, misstate, dan ketepatwaktuan penyusunan laporan keuangan SKPD.

Pada penelitian ini variabel disclosure, cost and benefit, responsibility, misstate, dan ketepatwaktuan penyusunan laporan keuangan SKPD sebagai variabel yang akan diukur dan diperbandingkan antara dua kelompok sampel (PPK dan Bendahara SKPD) yang memiliki faktor-faktor individual yang berbeda (locus of control, lama menjabat, gender, equity sensitivity, latar belakang pendidikan dan self efficacy). Kerangka pikir tersebut dapat dijelaskan dalam Gambar 2.1. berikut ini : 


\section{Gambar 1.}

\section{Kerangka Pemikiran Penelitian}

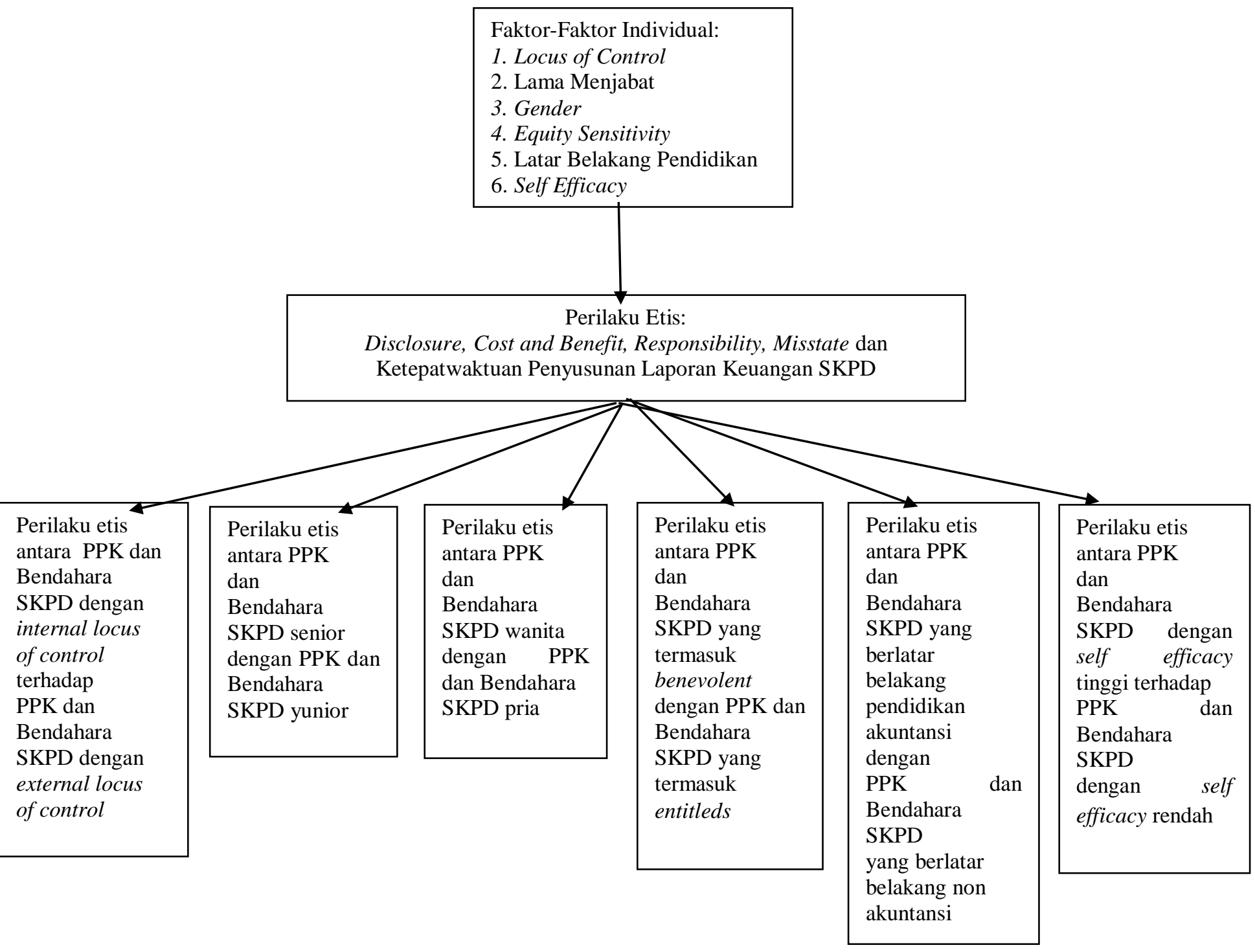

\section{METODE PENELITIAN}

Populasi dari penelitian ini adalah pegawai yang bekerja pada fungsi akuntansi pada SKPD di Kabupaten Sarolangun yang terdiri dari Pejabat Penatausahaan Keuangan (PPK) yang berjumlah 49 orang, Bendahara Penerimaan yang berjumlah 13 orang, Bendahara Pengeluaran yang berjumlah 50 orang dan Bendahara Pengeluaran Pembantu yang berjumlah 61 orang dengan total keseluruhan populasi yang berjumlah 173 orang.

Sampel dalam penelitian ini menggunakan purposive/judgement sampling Ukuran sampel yang digunakan dalam penelitian ini dihitung dengan menggunakan Rumus Slovin dengan hasil sampel sebesar 121 orang dengan rincian untuk PPK sebanyak 34 orang, Bendahara Penerimaan sebanyak 10 orang, Bendahara Pengeluaran sebanyak 35 orang dan Bendahara Pengeluaran Pembantu sebanyak 42 orang.

Penelitian ini dilakukan melalui survey dengan menggunakan questionaire. Untuk mendukung penelitian ini diperlukan data sekunder yang berhubungan dengan obyek 
penelitian. Penelitian ini merupakan pengujian hipotesis (hypothesis testing) yang menguji hipotesis. Kuesioner dalam penelitian ini terdiri dari lima bagian pertanyaan : Bagian pertama, berisi tentang data responden; Bagian kedua, berisi tentang pernyataan locus of control yang dikembangkan oleh Spector (1988) yang kemudian digunakan oleh Reiss dan Mitra (1998); Bagian ketiga, berisi tentang pernyataan equity sensitivity yang dikembangkan oleh Huseman (1985) yang kemudian digunakan oleh Reiss dan Mitra (1998); Bagian keempat, berisi tentang pernyataan self efficacy yang dikembangkan oleh Jones (198Jenis data yang digunakan dalam penelitian ini adalah data primer. Pengumpulan data akan dilakukan melalui survei kuesioner yang diantar dan diambil sendiri oleh peneliti terhadap fungsi akuntansi pada Satuan Kerja Perangkat Daerah (SKPD). Hal ini dimaksudkan untuk mengantisipasi kemungkinan salah interprestasi dalam mengartikan item-item kuesioner oleh responden dan menghindari kuesioner diisi oleh orang yang tidak kompeten. Responden dalam penelitian ini adalah Pejabat Penatausahaan Keuangan (PPK), Bendahara Penerimaan, Bendahara Pengeluaran dan Bendahara Pengeluaran Pembantu. Lokasi penelitian ini dilakukan terbatas di Kabupaten Sarolangun6) yang kemudian digunakan oleh Bandura (1997) dan Bagian kelima, berisi tentang pernyataan etika dalam penyusunan laporan keuangan yang digunakan oleh Yulianty

Kuesioner yang digunakan untuk mengumpulkan data perlu diuji validitas dan reliabilitas dengan tujuan agar kuesioner tersebut dapat menghasilkan apa yang diharapkan 2005). Penelitian ini menggunakan instrumen yang telah digunakan oleh penelitian-penelitian sebelumnya, sehingga validitas dan reliabilitasnya dapat dipertanggungjawabkan. Uji validitas menggunakan analisis faktor dengan tujuan untuk mengetahui kevalidan butir-butir pertanyaan untuk masing-masing variabel atau untuk mengetahui validitas konstruk. Asumsi yang mendasari dapat tidaknya digunakan analisis faktor adalah data matrik harus memiliki korelasi yang cukup (sufficient correlation). Alat uji yang digunakan untuk mengukur tingkat interkorelasi tersebut adalah Kaiser-Meyer-Olkin Measure of Sampling Adequacy (KMO MSA) dan nilai factor loading. Kaiser-MeyerOlkin Measure of Sampling Adequacy (KMO MSA) digunakan untuk menilai apakah proses pengambilan sampel sudah memadai atau belum. Jika nilai KMO MSA rendah maka dapat dipertimbangkan untuk membuang variabel atau butir pertanyaan tersebut. Nilai KMO MSA (Measure of Sampling Adequacy) yang diharapkan lebih besar dari 0.50 sehingga data yang dikumpulkan dapat dikatakan tepat untuk proses analisis faktor. Factor loading digunakan untuk menilai besarnya hubungan antara faktor dengan konstruknya. Nilai factor loading yang diharapkan adalah lebih besar dari 0,40.

Uji reliabilitas dilakukan dengan cara menghitung nilai cronbach alpha dari masing-masing instrumen dalam suatu variabel. Nilai cut off untuk menentukan reliabilitas suatu instrumen adalah nilai cronbach alpha lebih dari 0.60. Teknik uji normalitas yang digunakan adalah KolmogorovSmirnov. Uji normalitas ini dilakukan terhadap distribusi variabel disclosure (D), cost and benefit (C), responsibility (R), misstate (M) dan ketepatwaktuan (K). Kriteria dalam pengujian normalitas dalam pengujian ini adalah jika $p$-value lebih kecil dari tingkat signifikansi penelitian 5\%, maka data 
variabel terdistribusi secara tidak normal. Jika p-value lebih besar dari tingkat signifikansi penelitian $5 \%$, maka data variabel terdistribusi secara normal

Pengujian hipotesis dalam penelitian ini dilakukan untuk mengetahui perbedaan perilaku etis di antara sampel penelitian berdasarkan faktor-faktor individual dengan menggunakan uji beda $t$-test. Uji beda t-test digunakan untuk menentukan apakah dua sampel yang tidak berhubungan memiliki nilai rata-rata yang berbeda. Dalam uji beda t-test, pengujian dilakukan dengan membandingkan perbedaan antara dua nilai rata-rata dengan standart error dari perbedaan rata-rata dua sampel yang tidak berhubungan tersebut. $t$-test yang dipakai adalah Independent Sample $t$-test, untuk menguji signifikansi perbedaan mean dari dua kelompok sampel yang independen. Tes ini digunakan untuk menguji pengaruh variabel independen terhadap variabel dependen.

\section{HASIL DAN PEMBAHASAN}

Teknik pengujian instrument untuk penelitian ini terdiri atas Uji Validitas dan Uji Reliabilitas, dengan menggunakan one shoot method, yaitu dengan menggunakan reliability analysis scale (Cronbach's Alpha).

\section{Uji Validitas}

Pengambilan keputusan untuk uji validitas adalah dengan melihat korelasi masing-masing indikator terhadap total skor konstruk yang menunjukkan hasil signifikan, sehingga dapat disimpulkan bahwa pertanyaan tersebut valid. nilai signifikansi untuk tingkat korelasi dari masing-masing item pertanyaan pada variabel disclosure adalah sebesar 0,000-0,008 yang lebih kecil dari tingkat signifikansi penelitian 5\%, sehingga dapat dinyatakan bahwa item-item pertanyaan dalam variabel tersebut secara statistik valid untuk digunakan dalam penelitian ini.

\section{Uji Reabilitas}

Hasil uji reliabilitas untuk variabel disclosure menghasilkan Cronbach's Alpha sebesar 0,790, sehingga dapat disimpulkan bahwa pengujian instrument untuk variabel disclosure adalah reliabel, karena nilai Cronbach's Alpha 0,790>0,60. hasil uji reliabilitas untuk variabel cost and benefit menghasilkan Cronbach's Alpha sebesar 0,776, sehingga dapat disimpulkan bahwa pengujian instrument untuk variabel cost and benefit adalah reliabel, karena nilai Cronbach's Alpha 0,776 > 0,60. hasil uji reliabilitas untuk variabel responsibility menghasilkan Cronbach's Alpha sebesar 0,714, sehingga dapat disimpulkan bahwa pengujian instrument untuk variabel responsibility adalah reliabel, karena nilai Cronbach's Alpha 0,714 > 0,60. hasil uji reliabilitas untuk variabel misstate menghasilkan Cronbach's Alpha sebesar 0,808, sehingga dapat disimpulkan bahwa pengujian instrument untuk variabel misstate adalah reliabel, karena nilai Cronbach's Alpha 0,808 > 0,60. hasil uji reliabilitas untuk variabel ketepatwaktuan menghasilkan Cronbach's Alpha sebesar 0,832, sehingga dapat disimpulkan bahwa pengujian instrumen untuk variabel ketepatwaktuan adalah reliabel, karena nilai Cronbach's Alpha 0,832 > 0,60

\section{Uji Normalitas}

Hasil pengujian normalitas data untuk variabel disclosure, cost and benefit, responsibility, misstate dan ketepatwaktuan mengindikasikan bahwa keseluruhan data variabel tidak terdistribusi secara normal. Hasil ini diindikasikan oleh nilai asymp sig. (2- 
tailed) yang lebih kecil dari $5 \%$, yaitu 0,000 untuk disclosure, 0,047 untuk cost and benefit, 0,000 untuk responsibility, 0,017 untuk misstate dan 0,001 untuk ketepatwaktuan. Karena disclosure, cost and benefit, responsibility, misstate dan ketepatwaktuan mempunyai data yang terdistribusi secara tidak normal, maka dalam pengujian beda rata-rata menggunakan alat uji mann whitney rank test.

\section{HASIL DAN PEMBAHASAN}

Dalam pengujian hipotesis, penelitian ini dapat menggunakan statistic parametric dengan alat uji independent-test jika data variabel terdistribusi secara normal, akan tetapi apabila data variabel tidak terdistribusi secara normal, penelitian ini akan menggunakan statistic non parametric dengan alat uji mann whitney rank test.

Atas dasar pengujian normalitas di atas dapat dinyatakan bahwa data variabel disclosure, cost and benefit, responsibility, misstate dan ketepatwaktuan mempunyai data yang terdistribusi secara tidak normal sehingga dapat disimpulkan bahwa dalam pengujian hipotesis semua data variabel akan menggunakan statistic non parametric dengan alat uji mann whitney rank test.

Hasil pengujian mann whitney rank test untuk variabel disclosure, cost and benefit, responsibility, misstate dan ketepatwaktuan berdasarkan tingkat locus of control dapat disajikan dalam tabel 4.11. berikut ini.

Tabel 1

Hasil Uji Mann Whitney Rank Test

Perilaku Etis Berdasarkan Tingkat Locus of Control

\begin{tabular}{|l|r|r|r|r|r|}
\hline & $\begin{array}{r}\text { DISCLOSUR } \\
\text { E }\end{array}$ & $\begin{array}{c}\text { COST } \\
\text { BENEFIT }\end{array}$ & $\begin{array}{r}\text { RESPONSIBILIT } \\
\text { Y }\end{array}$ & $\begin{array}{r}\text { MISSTAT } \\
\text { E }\end{array}$ & $\begin{array}{r}\text { KETEPAT- } \\
\text { WAKTUAN }\end{array}$ \\
\hline Mann-Whitney U & 1340.500 & 1558.500 & 1424.000 & 1181.000 & 1642.500 \\
Wilcoxon W & 3051.500 & 3269.500 & 3135.000 & 2892.000 & 3472.500 \\
Z & -2.191 & -.989 & -1.737 & -3.040 & -.537 \\
Asymp. Sig. (2-tailed) & .028 & .323 & .082 & .002 & .591 \\
\hline
\end{tabular}

Tabel 1 di atas menunjukan tingkat signifikansi mann whitney rang test untuk variabel disclosure sebesar 0,028 , variabel cost and benefit sebesar 0,323 , variabel responsibility sebesar 0,082 , variabel misstate sebesar 0,002 dan variabel ketepatwaktuan sebesar 0,591 .

Analisis uji mann whitney rank test di atas menunjukkan bahwa variabel disclosure mempunyai signifikansi sebesar 0,028 yang artinya lebih kecil dari tingkat signifikansi $5 \%$. Hasil ini mengindikasikan bahwa di antara internal locus of control dengan external locus of control terdapat perbedaan yang signifikan dalam hal disclosure terkait dengan etika penyusunan laporan keuangan SKPD pada Pemerintah Kabupaten Sarolangun. Berdasarkan nilai mean rank mengindikasikan bahwa PPK dan Bendahara SKPD dengan internal locus of control sebesar 66,16 lebih berperilaku etis di banding PPK dan Bendahara SKPD dengan external locus of control sebesar 52,61 terkait dengan disclosure dalam etika penyusunan laporan keuangan SKPD pada Pemerintah Kabupaten Sarolangun. Variabel misstate mempunyai signifikansi sebesar 0,002 yang juga mengindikasikan bahwa antara internal locus of control dengan external locus of control terdapat perbedaan yang signifikan dalam hal 
misstate terkait dengan etika penyusunan laporan keuangan SKPD Sarolangun. Berdasarkan nilai mean rank mengindikasikan bahwa PPK dan Bendahara SKPD dengan internal locus of control sebesar 68,82 lebih berperilaku etis di banding PPK dan Bendahara SKPD dengan external locus of control sebesar 49,86 terkait dengan misstate dalam etika penyusunan laporan keuangan SKPD pada Pemerintah Kabupaten Sarolangun.

Berdasarkan tingkat signifikansi $10 \%$, variabel responsibility yang mempunyai signifikansi 0,082, menunjukkan bahwa di antara internal locus of control dengan external locus of control juga terdapat perbedaan yang terkait dengan etika penyusunan laporan keuangan SKPD pada Pemerintah Kabupaten Sarolangun. Berdasarkan nilai mean rank mengindikasikan bahwa PPK dan pada Pemerintah Kabupaten signifikan dalam hal responsibility

Bendahara SKPD dengan internal locus of control sebesar 64,77 lebih berperilaku etis di banding PPK dan Bendahara SKPD dengan external locus of control sebesar 54,05 terkait dengan responsibility dalam etika penyusunan laporan keuangan SKPD pada Pemerintah Kabupaten Sarolangun. Hasil pengujian tersebut mengindikasikan bahwa tidak terdapat perbedaan yang signifikan antara PPK dan Bendahara SKPD dengan internal locus of control terhadap PPK dan Bendahara SKPD dengan external locus of control dalam etika penyusunan laporan keuangan SKPD pada Pemerintah Kabupaten Sarolangun yang dinyatakan dengan variabel cost and benefit dan ketepatwaktuan..

Hasil pengujian mann whitney rank test untuk variabel disclosure, cost and benefit, responsibility, misstate dan ketepatwaktuan berdasarkan lama menjabat dapat disajikan dalam tabel 4.12. berikut ini

\section{Tabel 2}

Hasil Uji Mann Whitney Rank Test

Perilaku Etis Berdasarkan Lama Menjabat

\begin{tabular}{|l|r|r|r|r|r|}
\hline & $\begin{array}{r}\text { DISCLOSUR } \\
\text { E }\end{array}$ & $\begin{array}{c}\text { COST } \\
\text { BENEFIT }\end{array}$ & $\begin{array}{r}\text { RESPONSIBILIT } \\
\text { Y }\end{array}$ & $\begin{array}{c}\text { MISSTAT } \\
\text { E }\end{array}$ & $\begin{array}{r}\text { KETEPAT- } \\
\text { WAKTUAN }\end{array}$ \\
\hline Mann-Whitney U & 1582.500 & 1352.000 & 1558.000 & 1528.500 & 1077.500 \\
Wilcoxon W & 2485.500 & 4278.000 & 4484.000 & 4454.500 & 1980.500 \\
Z & -.077 & -1.388 & -.218 & -.383 & -2.980 \\
Asymp. Sig. (2- & .938 & .165 & .827 & .701 & .003 \\
tailed) & & & & & \\
\hline
\end{tabular}

Tabel 2 di atas menunjukan tingkat signifikansi mann whitney rank test untuk variabel disclosure sebesar 0,938, variabel cost and benefit sebesar 0,165 , variabel responsibility sebesar 0,827 , variabel misstate sebesar 0,701 dan variabel ketepatwaktuan sebesar 0,003 .

Analisis uji mann whitney rang test di atas menunjukkan bahwa variabel ketepatwaktuan mempunyai signifikansi sebesar 0,003 yang artinya lebih kecil dari tingkat signifikansi $5 \%$.
Hasil ini mengindikasikan bahwa di antara PPK dan Bendahara SKPD senior dengan PPK dan Bendahara SKPD yunior terdapat perbedaan yang signifikan dalam hal ketepatwaktuan terkait dengan etika penyusunan laporan keuangan SKPD pada Pemerintah Kabupaten Sarolangun. Berdasarkan nilai mean rank mengindikasikan bahwa PPK dan Bendahara SKPD senior sebesar 66,32 lebih berperilaku etis di banding PPK dan Bendahara SKPD yunior sebesar 
47,15 terkait dengan ketepatwaktuan dalam etika penyusunan laporan cost and misstate benefit, responsibility, keuangan SKPD pada Pemerintah Kabupaten Sarolangun.

berdasarkan gender dapat disajikan Hasil pengujian mann whitney rank test untuk variabel disclosure,

Tabel 3

Hasil Uji Mann Whitney Rank Test Perilaku Etis Berdasarkan Gender

\begin{tabular}{|l|r|r|r|r|r|}
\hline & $\begin{array}{c}\text { DISCLOSUR } \\
\text { E }\end{array}$ & $\begin{array}{c}\text { COST } \\
\text { BENEFIT }\end{array}$ & $\begin{array}{r}\text { RESPONSIBILIT } \\
\text { Y }\end{array}$ & $\begin{array}{r}\text { MISSTAT } \\
\text { E }\end{array}$ & $\begin{array}{r}\text { KETEPAT- } \\
\text { WAKTUAN }\end{array}$ \\
\hline Mann-Whitney U & 1531.000 & 1574.000 & 1192.500 & 1560.500 & 1665.000 \\
Wilcoxon W & 3016.000 & 3059.000 & 2677.500 & 3045.500 & 3150.000 \\
Z & -1.085 & -.842 & -2.955 & -.914 & -.348 \\
Asymp. Sig. (2- & .278 & .400 & .003 & .361 & .728 \\
tailed) & & & & & \\
\hline
\end{tabular}

Tabel 3 di atas menunjukan tingkat signifikansi mann whitney rank test untuk variabel disclosure sebesar 0,278 , variabel cost and benefit sebesar 0,400 , variabel responsibility sebesar 0,003 , variabel misstate sebesar 0,361 dan variabel ketepatwaktuan sebesar 0,728 .

Analisis uji mann whitney rang test di atas menunjukkan bahwa variabel responsibility mempunyai signifikansi sebesar 0,003 yang artinya lebih kecil dari tingkat signifikansi $5 \%$. Hasil ini mengindikasikan bahwa di antara PPK dan Bendahara SKPD pria dengan PPK dan Bendahara SKPD wanita terdapat perbedaan yang signifikan dalam hal responsibility terkait dengan etika penyusunan laporan keuangan SKPD pada Pemerintah Kabupaten Sarolangun. Berdasarkan nilai mean rank mengindikasikan bahwa PPK dan Bendahara SKPD wanita sebesar 67,87 lebih berperilaku etis di banding PPK dan Bendahara SKPD pria sebesar 49,58 terkait dengan responsibility dalam etika penyusunan laporan keuangan SKPD pada Pemerintah Kabupaten Sarolangun.

Hasil pengujian mann whitney rank test untuk variabel disclosure, cost and benefit, responsibility, misstate dan ketepatwaktuan berdasarkan tingkat equity sensitivity dapat disajikan dalam tabel 4.14. berikut ini.

\section{Tabel 4.}

Hasil Uji Mann Whitney Rank Test

Perilaku Etis Berdasarkan Tingkat Equity Sensitivity

\begin{tabular}{|l|r|r|r|r|r|}
\hline & $\begin{array}{r}\text { DISCLOSUR } \\
\text { E }\end{array}$ & COST & RESPONSIBILIT & & KETEPAT- \\
\hline Mann-Whitney U & 1269.50 & 1147.000 & 1151.500 & 1234.500 & 997.500 \\
Wilcoxon W & 1935.500 & 1813.000 & 1817.500 & 1900.500 & 1663.500 \\
Z & -1.230 & -1.946 & -1.936 & -1.426 & -2.860 \\
Asymp. Sig. (2- & .219 & .052 & .053 & .154 & .004 \\
tailed) & & & & & Y \\
\hline
\end{tabular}

Tabel $4 \mathrm{di}$ atas menunjukan 0,219, variabel cost and benefit sebesar tingkat signifikansi mann whitney rank 0,052, variabel responsibility sebesar test untuk variabel disclosure sebesar 0,053, variabel misstate sebesar 0,154 
dan variabel ketepatwaktuan sebesar 0,004 .

Analisis uji mann whitney rang test $\mathrm{di}$ atas menunjukkan bahwa variabel cost and benefit mempunyai signifikansi sebesar 0,052 yang artinya sama dengan tingkat signifikansi $5 \%$. Hasil ini mengindikasikan bahwa di antara PPK dan Bendahara SKPD benevolents dengan PPK dan Bendahara SKPD entitleds terdapat perbedaan yang signifikan dalam hal cost and benefit terkait dengan etika penyusunan laporan keuangan SKPD pada Pemerintah Kabupaten Sarolangun. Berdasarkan nilai mean rank mengindikasikan bahwa PPK dan Bendahara SKPD benevolent sebesar 63,51 lebih berperilaku etis di banding PPK dan Bendahara SKPD entitleds sebesar 50,36 terkait dengan cost and benefit dalam etika penyusunan laporan keuangan SKPD pada Pemerintah Kabupaten Sarolangun.

\section{Variabel}

responsibility

mempunyai signifikansi sebesar 0,053 yang artinya sama dengan tingkat signifikansi $5 \%$. Hasil ini mengindikasikan bahwa di antara PPK dan Bendahara SKPD benevolents dengan PPK dan Bendahara SKPD entitleds terdapat perbedaan yang signifikan dalam hal responsibility terkait dengan etika penyusunan laporan keuangan SKPD pada Pemerintah Kabupaten Sarolangun. Berdasarkan nilai mean rank mengindikasikan bahwa PPK dan Bendahara SKPD benevolent sebesar 63,46 lebih berperilaku etis di banding PPK dan Bendahara SKPD entitleds sebesar 50,49 terkait dengan responsibility dalam etika penyusunan laporan keuangan SKPD pada Pemerintah Kabupaten Sarolangun.

Variabel ketepatwaktuan juga mempunyai signifikansi sebesar 0,004 yang artinya memiliki nilai lebih kecil dari tingkat signifikansi 5\%. Hasil ini mengindikasikan bahwa di antara PPK dan Bendahara SKPD benevolents dengan PPK dan Bendahara SKPD entitleds terdapat perbedaan yang signifikan dalam hal ketepatwaktuan terkait dengan etika penyusunan laporan keuangan SKPD pada Pemerintah Kabupaten Sarolangun. Berdasarkan nilai mean rank mengindikasikan bahwa PPK dan Bendahara SKPD benevolent sebesar 65,34 lebih berperilaku etis di banding PPK dan Bendahara SKPD entitleds sebesar 46,21 terkait dengan ketepatwaktuan dalam etika penyusunan laporan keuangan SKPD pada Pemerintah Kabupaten Sarolangun.

Hasil pengujian mann whitney rank test untuk variabel disclosure, cost and benefit, responsibility, misstate dan ketepatwaktuan berdasarkan latar belakang pendidikan dapat disajikan dalam tabel 4.15. berikut ini.

Tabel 5.

Hasil Uji Mann Whitney Rank Test Perilaku Etis Berdasarkan Latar Belakang Pendidikan

\begin{tabular}{|l|r|r|r|r|r|}
\hline & DISCLOSUR & COST & RESPONSIBILIT & & KETEPAT- \\
& \multicolumn{1}{|c|}{ E } & BENEFIT & Y & MISSTATE & WAKTUAN \\
\hline Mann-Whitney U & 965.000 & 939.000 & 780.000 & 816.000 & 971.000 \\
Wilcoxon W & 5718.000 & 5692.000 & 5533.000 & 5569.000 & 5724.000 \\
Z & -.384 & -.566 & -1.714 & -1.440 & -.342 \\
Asymp. Sig. (2- & .701 & .571 & .086 & .150 & .733 \\
tailed) & & & & & \\
\hline
\end{tabular}


Tabel 5. di atas menunjukan tingkat signifikansi mann whitney rank test untuk variabel disclosure sebesar 0,701, variabel cost and benefit sebesar 0,571, variabel responsibility sebesar 0,086 , variabel misstate sebesar 0,150 dan variabel ketepatwaktuan sebesar 0,733 .

Berdasarkan tingkat signifikansi
$10 \%, \quad$ variabel responsibility mempunyai signifikansi sebesar 0,086 yang artinya memiliki nilai lebih kecil dari tingkat signifikansi $10 \%$. Hasil ini mengindikasikan bahwa di antara PPK dan Bendahara SKPD yang mempunyai latar belakang pendidikan akuntansi dengan PPK dan Bendahara SKPD yang mempunyai latar belakang pendidikan non akuntansi terdapat perbedaan yang signifikan dalam hal responsibility terkait dengan etika penyusunan laporan keuangan SKPD pada Pemerintah Kabupaten Sarolangun. Berdasarkan nilai mean rank mengindikasikan bahwa PPK dan Bendahara SKPD yang mempunyai latar belakang pendidikan akuntansi sebesar 70,86 lebih berperilaku etis di banding PPK dan Bendahara SKPD yang mempunyai latar belakang pendidikan non akuntansi sebesar 57,04 terkait dengan responsibility dalam etika penyusunan laporan keuangan SKPD pada Pemerintah Kabupaten Sarolangun.

Hasil pengujian mann whitney rank test untuk variabel disclosure, cost and benefit, responsibility, misstate dan ketepatwaktuan berdasarkan tingkat self efficacy dapat disajikan dalam tabel 4.16. berikut ini.

Tabel 6.

Hasil Uji Mann Whitney Rank Test

Perilaku Etis Berdasarkan Tingkat Self Efficacy

\begin{tabular}{|l|r|r|r|r|r|}
\hline & $\begin{array}{c}\text { DISCLOSUR } \\
\text { E }\end{array}$ & $\begin{array}{c}\text { COST } \\
\text { BENEFIT }\end{array}$ & $\begin{array}{r}\text { RESPONSIBILIT } \\
\text { Y }\end{array}$ & MISSTATE & WAKTUAN \\
\hline Mann-Whitney U & 1647.000 & 1550.500 & 1629.500 & 1677.500 & 1395.500 \\
Wilcoxon W & 3187.000 & 3090.500 & 3645.500 & 3693.500 & 2935.500 \\
Z & -.470 & -.994 & -.567 & -.300 & -1.859 \\
Asymp. Sig. (2- & .638 & .320 & .571 & .764 & .063 \\
tailed) & & & & & \\
\hline
\end{tabular}

Tabel 6 di atas menunjukan tingkat signifikansi mann whitney rank test untuk variabel disclosure sebesar 0,638, variabel cost and benefit sebesar 0,320 , variabel responsibility sebesar 0,571 , variabel misstate sebesar 0,764 dan variabel ketepatwaktuan sebesar 0,063 .

Berdasarkan tingkat signifikansi 10\%, variabel ketepatwaktuan mempunyai signifikansi sebesar 0,063 yang artinya memiliki nilai lebih kecil dari tingkat signifikansi $10 \%$. Hasil ini mengindikasikan bahwa di antara PPK dan Bendahara SKPD yang mempunyai self efficacy tinggi dengan PPK dan Bendahara SKPD yang mempunyai self efficacy rendah terdapat perbedaan yang signifikan dalam hal ketepatwaktuan terkait dengan etika penyusunan laporan keuangan SKPD pada Pemerintah Kabupaten Sarolangun. Berdasarkan nilai mean rank mengindikasikan bahwa PPK dan Bendahara SKPD yang mempunyai self efficacy tinggi sebesar 64,85 lebih berperilaku etis di banding PPK dan Bendahara SKPD yang mempunyai self efficacy rendah sebesar 53,37 terkait dengan ketepatwaktuan dalam etika penyusunan laporan keuangan SKPD pada Pemerintah Kabupaten Sarolangun. 


\section{SIMPULAN}

Hasil pengujian data terkait analisa faktor-faktor individual PPK dan Bendahara SKPD di Pemerintah Daerah Kabupaten Sarolangun dalam etika penyusunan laporan keuangan SKPD yang telah diperoleh dan dipaparkan dalam bab sebelumnya mendasari pengambilan kesimpulan dalam penelitian ini :

1. Tidak terdapat perbedaan antara PPK dan Bendahara SKPD dengan internal locus of control terhadap PPK dan Bendahara SKPD dengan external locus of control dalam etika penyusunan laporan keuangan SKPD pada Pemerintah Kabupaten Sarolangun yang dinyatakan dengan variabel cost and benefit dan ketepatwaktuan. Perbedaan hanya terdapat pada variabel disclosure, misstate dan variabel responsibility. Tidak adanya perbedaan disebabkan PPK dan Bendahara SKPD hanya berpikir bagaimana cara membuat laporan keuangan untuk segera dilaporkan dan kurang memperhatikan etika penyusunan laporan keuangan yang nantinya sangat berpengaruh terhadap nilai informasi laporan keuangan yang akan digunakan oleh instansi.

2. Tidak terdapat perbedaan antara PPK dan Bendahara SKPD senior dengan PPK dan Bendahara SKPD yunior dalam etika penyusunan laporan keuangan SKPD pada Pemerintah Kabupaten Sarolangun yang dinyatakan dengan variabel disclosure, cost and benefit, responsibility dan misstate. Perbedaan hanya terdapat pada variabel ketepatwaktuan. Perbedaan ketepatwaktuan terjadi disebabkan PPK dan Bendahara SKPD senior berdasarkan lama menjabat ataupun pengalaman kerjanya lebih memahami Standar Akuntansi Pemerintahan (SAP) dan menguasai aplikasi penyusunan laporan keuangan sehingga menghasilkan laporan keuangan SKPD lebih tepat waktu bila dibandingkan dengan PPK dan Bendahara SKPD yunior. Sedangkan tidak adanya perbedaan disebabkan para PPK dan Bendahara SKPD dalam penelitian ini hanya berpikir bagaimana laporan keuangan disusun untuk segera dilaporkan tanpa memperhatikan etika-etika lainnya dalam pengungkapan laporan keuangan, sementara pada sektor pemerintahan kecenderungan untuk memahami etika pelaporan keuangan sangatlah kurang, baik para PPK dan Bendahara SKPD senior maupun PPK dan Bendahara SKPD yunior.

3. Tidak terdapat perbedaan antara PPK dan Bendahara SKPD pria dengan PPK dan Bendahara SKPD wanita terhadap etika penyusunan laporan keuangan SKPD pada Pemerintah Kabupaten Sarolangun yang dinyatakan dengan variabel disclosure, cost and benefit, misstate dan ketepatwaktuan. Perbedaan hanya terdapat pada variabel responsibility. Tidak terdapat perbedaan tersebut menunjukkan bahwa pada hakikatnya pria dan wanita itu sama didalam menyelesaikan pekerjaan, namun perbedaannya adalah pada kemampuan yang dimiliki oleh masing-masing individu PPK maupun Bendahara SKPD ketika mereka menyusun laporan keuangan SKPD.

4. Tidak terdapat perbedaan antara PPK dan Bendahara SKPD yang merupakan benevolent dengan PPK dan Bendahara SKPD yang merupakan entitleds terhadap etika penyusunan laporan keuangan SKPD pada Pemerintah Kabupaten Sarolangun yang dinyatakan dengan 
disclosure dan misstate. Perbedaan hanya terdapat pada variabel cost and benefit, responsibility dan ketepatwaktuan. Hal ini dapat disebabkan karena pada sektor pemerintahan pemberian reward kepada PPK dan Bendahara SKPD yang bekerja keras dengan PPK dan Bendahara SKPD yang bekerja sekedarnya saja hampir dapat dikatakan sama. Oleh karena itu, berapapun jumlah input yang diberikan oleh seorang PPK ataupun Bendahara SKPD kurang lebih akan memperoleh jumlah output atau reward yang sama. Perbedaan terjadi disebabkan PPK dan Bendahara SKPD yang benevolent akan merasa adil ketika inputs yang mereka berikan lebih besar daripada outputs yang mereka terima, sehingga respon yang mereka berikan lebih cepat dibandingkan PPK dan Bendahara SKPD yang entitleds dalam penyampaian laporan keuangan SKPD secara tepat waktu dengan tujuan agar informasi laporan keuangan tersebut lebih banyak bermanfaat bagi pengguna laporan keuangan dibandingkan biaya yang dikeluarkan dalam penyusunan laporan keuangan tersebut.

5. Tidak terdapat perbedaan antara PPK dan Bendahara SKPD yang berlatar belakang pendidikan akuntansi dengan PPK dan Bendahara SKPD yang berlatar belakang pendidikan non akuntansi terhadap etika penyusunan laporan keuangan SKPD pada Pemerintah Kabupaten Sarolangun yang dinyatakan dengan variabel disclosure, cost and benefit, misstate dan ketepatwaktuan. Perbedaan hanya terdapat pada variabel responsibility. Tidak adanya perbedaan antara PPK dan Bendahara SKPD yang berlatar belakang pendidikan akuntansi dengan non akuntansi ini dapat disebabkan oleh alasan bahwa akuntansi sektor publik (pemerintah) masih dalam tahap implementasi awal yang tentunya banyak membutuhkan sosialisasi kepada para PPK dan Bendahara SKPD dan dapat pula didasari oleh alasan bahwa peraturan teknis pelaksanaan akuntansi pemerintah selalu mengalami perubahan untuk penyempurnaan sehingga membutuhkan respon yang cepat dari PPK dan Bendahara SKPD untuk melakukan penyesuaian terhadap peraturan-peraturan yang mengalami perubahan tersebut. Namun, pada akhirnya penelitian ini menunjukkan bahwa PPK dan Bendahara SKPD yang berlatar belakang pendidikan akuntansi dengan tingkat pengetahuan yang dimilikinya akan lebih cepat merespon segala perubahan akuntansi yang terjadi bila dibandingkan dengan PPK dan Bendahara SKPD yang berlatar belakang pendidikan non akuntansi.

6. Tidak terdapat perbedaan antara PPK dan Bendahara SKPD yang mempunyai self efficacy tinggi dengan PPK dan Bendahara SKPD yang yang mempunyai self efficacy rendah terhadap etika penyusunan laporan keuangan SKPD pada Pemerintah Kabupaten Sarolangun yang dinyatakan dengan variabel disclosure, cost and benefit, responsibility dan misstate. Perbedaan hanya terdapat pada variabel ketepatwaktuan. Hal ini menunjukkan bahwa PPK dan Bendahara SKPD yang mempunyai kepercayaan diri yang tinggi selalu berusaha menyampaikan laporan keuangan SKPD tepat pada waktunya bila dibandingkan dengan PPK dan Bendahara SKPD yang mempunyai kepercayaan diri yang 
rendah karena mereka merasa bahwa informasi laporan keuangan akan menjadi tidak relevan jika waktu penyampaiannya terlambat dan tentunya akan memperlambat pula PPKD didalam menyusun serta menyampaikan Laporan Keuangan Pemerintah Daerah kepada DPRD. Self efficacy yang rendah disebabkan kurangnya kepercayaan diri dari PPK dan Bendahara SKPD akan kemampuan yang mereka miliki dalam memahami dan menggunakan aplikasi di bidang keuangan, sehingga diperlukan pelatihan dan sosialisasi secara berkala guna meningkatkan kemampuan mereka dalam penyusunan laporan keuangan SKPDnya.

\section{Saran}

Penelitian ini sebaiknya juga dilanjutkan dengan menguji pengaruh variabel-variabel yang mengalami perbedaan terhadap etika penyusunan laporan keuangan tersebut, sehingga akan dapat diketahui secara langsung pengaruh faktor-faktor individual tersebut terhadap etika penyusunan laporan keuangan.

\section{DAFTAR PUSTAKA}

Alvin A. Arens dkk. 2006. Auditing dan Jasa Assurance. Jilid 1. Jakarta : Erlangga.

Arifiyani, Hesti Arlich. 2012. Pengaruh Pengendalian Intern, Kepatuhan dan Kompensasi Manajemen Terhadap Perilaku Etis Karyawan (Studi Kasus PT. Adi Satria Abadi Yogyakarta). Jurnal Nominal, Volume I Nomor I : 5-21.

Bandura, Albert. 1997. Self - Efficacy. The Exercise of Control, W. $H$. Freeman and Company, United States of America.

Berninghausen, Jutta dan Brigit, Kerstan. 1992. Forging New
Paths : Feminist Social Methodology and Rural Women in Java. Zed Books Limited. London and New Jersey.

Bommer, M., C. Gratto, J. Gravander dan M. Tuttle. 1987. A Behavioral Model of Ethical and Unethical Decision Making. Journal of Business Ethics, Vol. 6 : 265-280.

Chaplin, J. P. 2006. Kamus Psikologi Lengkap. Jakarta : PT. Raja Grafindo.

Fauzi, Achmad. 2001. Pengaruh Faktor-Faktor Individual terhadap Perilaku Etis Mahasiswa Akuntansi. Tesis Tidak Dipublikasikan. Program Pasca Sarjana, Universitas Gadjah Mada, Yogyakarta.

Febrianty. 2010. Pengaruh Gender, Locus of Control, Intellectual Capital, dan Ethical Sensitivity Terrhadap Perilaku Etis Mahasiswa Akuntansi pada Perguruan Tinggi (Survey pada Perguruan Tinggi di Kota Palembang). Jurnal Ilmiah Orasi Bisnis, Edisi Ke-IV, November.

Fontanella, Amy. 2010. Analisis Pengaruh Latar Belakang Pendidikan dan Pengetahuan Akuntansi Pengguna Terhadap Pemanfaatan Laporan Keuangan Pemerintah Daerah. Jurnal Akuntansi dan Manajemen. Volume 5 No. 2 Desember : 2230 .

Hamiseno, Erlina Winanti. 2010. Analisis Perbedaan Perilaku Etis Pelaku Akuntansi Berdasarkan Karakteristik Individu dalam Etika Penyusunan Laporan Keuangan Satuan Kerja Perangkat Daerah (Studi Kasus di Kabupaten Sukoharjo). Tesis Fakultas Ekonomi Universitas Sebelas Maret, Surakarta. 